DOI: $10.1515 /$ pts-2016-0023

\title{
THE DEVELOPMENT OF NANOTECHNOLOGIES AND ADVANCED MATERIALS INDUSTRY IN SCIENCE AND ENTREPRENEURSHIP: SOCIOECONOMIC AND TECHNICAL INDICATORS. A CASE STUDY OF LATVIA (PART ONE)
}

\author{
I. Geipele ${ }^{1}$, S. Geipele ${ }^{1}$, T. Staube ${ }^{1}$, G. Ciemleja ${ }^{1}$, N. Zeltins ${ }^{2}$, \\ ${ }^{1}$ Institute of Civil Engineering and Real Estate Economics, \\ Faculty of Engineering Economics and Management, \\ Riga Technical University, \\ 6-210 Kalnciema Str., LV-1048, Riga, LATVIA \\ E-mail: Ineta.Geipele@rtu.lv \\ ${ }^{2}$ Latvian MemberKommitte of World Energy Council \\ 21 Aizkraukles Str., LV-1006, Riga, LATVIA
}

The present scientific paper is the first part of two publications, where the authors obtain results from the scientific research presented in a series of works on the development of the nanotechnologies and advanced materials industry in science and entrepreneurship in Latvia. The study has a focus on finding proper socioeconomic and technical indicators. It provides resume on a scope of the study. The paper contains the developed structure of engineering economic indicator system, determined groups of indicators for assessment of the development of nanotechnologies and advanced materials industry in Latvia and results of the evaluation of the obtained statistics on the economic indicators.

Keywords: advanced materials, development of science, economic environment level, engineering economic indicator system, nanotechnologies, research.

\section{1, INTRODUCTION}

To ensure the effective development of the Latvian nano-field in science and entrepreneurship within the functioning institutional environment, it is necessary to perform an analysis of those indicators that characterise and/or pose a direct impact on the development of innovative material products and technological processes, as well as on the related industries and research, which are important factors for the production and commercialisation of future high technology and advanced materials according to the changes of global market and the development of technologies at present. 
The subject of the current research is economic, social and technical indicators. The research object is nanotechnologies and advanced materials industry in Latvia. To reach the aim of the study - to analyse the most important indicators characterising the level of development of nano-field in quantitative terms in Latvia, the following tasks are defined: (1) to identify the importance of the engineering economic indicators determined for the development of the advanced materials field in science in Latvia; (2) to provide comparison of the economic indicators found with that of other countries if applicable; (3) to generate the data according to the levels of the economic environment; (4) to provide recommendations for business sector representatives and for the improvement of the national support programme for research and science.

The authors performed the statistical, logical, data processing and comparative analysis, studied the primary and secondary sources of the scientific literature, made a scientific overview of theoretical aspects of the issue under consideration and examined a set of indicators. To provide an overview of market data, the authors used the results of the scientific and practical study performed on the operational profile and identity of innovative multifunctional material producers in Latvia. The survey was carried out from mid-December 2014 to mid-February 2015 [1].

\section{THEORETICAL FRAMEWORK AND SCIENTIFIC LITERATURE OVERVIEW}

To determine technological efficiency of nanotechnology, in different countries researchers (Gholizadeh et al. 2015) use the following variables (indicators):

1) Investment (share of research and development costs of GDP, public investment in science and nanotechnology);

2) Human capital (researchers in R\&D per capita; number of faculty members active in nanotechnology);

3) Technology (nanotechnology patent applications; number of nanotechnology patents per number of articles in the nano-field);

4) Industry (GDP per capita in purchasing power; GDP (purchasing power parity or ppp));

5) Science (national priorities of nanoscience; nano-articles per GDP (ppp); total number of citations of nano-articles; number of nano-articles per million people; local share of nanoscience, contribution to international cooperation in the production of nanoscience; citation index (h-index); average references per article; number of research centres in nanotechnology). However, the problem is due to the fact that data for these factors were not readily available in all countries [2].

In any field, a business activity oriented to the long term is dependent on the business environment and factors that make it up. According to the study by Dessi and Floris (2010), the economic assessment of nanotechnology business development should be carried out taking into account both the Porter five forces model, which is based on external forces, and the resource-based view (RBV), which combines the external or macro- and meso-environmental impact and the capabilities and 
resources characteristic of the development of company itself or micro environment. The resource approach confirms that enterprises differ from each other in resources at their disposal, and allocation of resources among enterprises is heterogeneous, which makes a difference in business operation [3].

Exactly the use of nanotechnologies in different sectors makes it necessary to identify the factors that influence the development of the field under discussion, how the effect is manifested and which indicators can assess this impact. The RBV approach demonstrates that enterprises with a set of rare and valuable resources operate at higher efficiency. In turn, sustainable market position is associated with successful innovation activity when the introduction of new product types offsets falling profitability [4], as product and process innovations create a new value through the altered product characteristics and lower costs [5]. The company's technological innovations and operation in a free-market environment are an essential precondition for generating new ideas and satisfying consumer needs, while reducing the impact on the ecological and social environment.

Using key performance indicators (KPIs), it is possible to create a set of company's financial and non-financial indicators that may most critically affect the company's ongoing operations and future opportunities [6]. The KPIs provide management decision-making process with the information concerning the company's tactics and operating parameters in order to follow the strategy set [7], and inform what should be done to significantly improve the company's operation [6], [8]. If the KPIs are formed as a system, they lead to the changes of quantitative or qualitative results in relation to the company's strategic aim [7]. The KPIs are more frequently used in the company's corporate social responsibility programmes, including indicators and criteria related to sustainability and describing the specifics of company's operations [9]. Consequently, the basis for the company to remain competitive in the future may be considered the proper identification of KPIs [10] with the aim to focus only on the most significant indicators, deselecting all the secondary ones and reducing their number to the so-called "keys". Systematisation of information is one of the prerequisites, since the KPI choice largely depends on possibilities to identify and process the information flow so that by drawing conclusions and making decisions it could be possible to use properly prepared information, and the process would become faster and, thus, more productive. This determines the critical elements of KPI selection process: 1) the choice of indicators; 2) the intelligibility and compliance of indicators with the company's operation processes; 3 ) the feasibility and credibility of indicator check process [10].

\section{METHODOLOGICAL SOLUTION}

The developed indicator groups of engineering economic system: economic, social, technical, scientific, legal, political, ecological, health and safety, information and communication, as well as management implementation [11] have been classified by the authors according to economic environment development levels or three dimensions.

All 10 groups of indicators operate at the macro, meso and micro levels. At the macro or global level, there are internationally recognised indicators that are 
used for national awareness and comparison of activity ratings on a global scale, and they are made available at officially recognised databases and organisation reports and/or websites. At the medium meso or national level of economic environment development, there are indicators that provide data for the assessment of national development promotion activities and functioning that would describe the extent of state support, as well as the public interest and activity rate for nano-industry development, including the provision of labour force and infrastructure at the local level. In turn, at the business or micro level, there are indicators that demonstrate the capacity of manufacturers operating in the local market for the commercialisation of nanomaterials, as well as the business capital capacity and maturity level to acquire and use new generation of nanotechnologies (see Fig. 1).

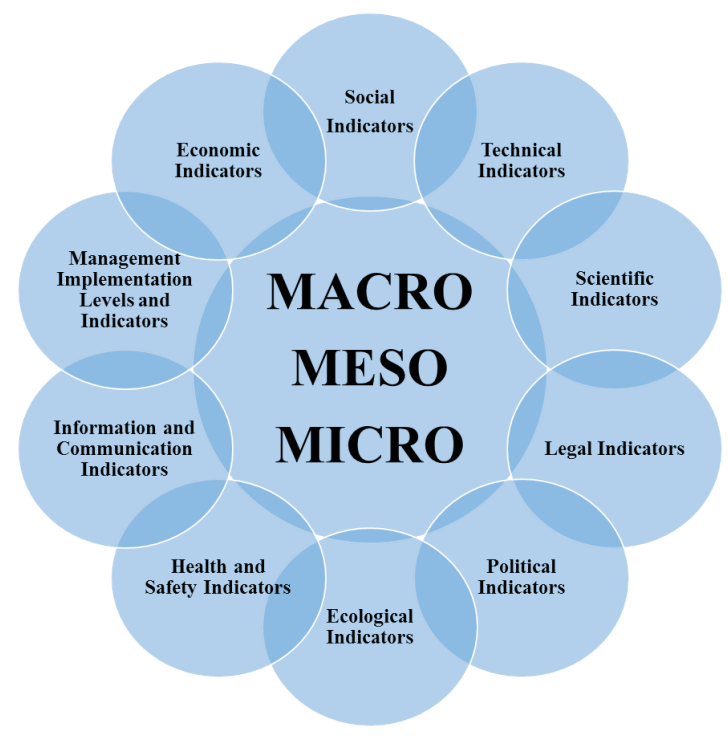

Fig. 1. Structure of engineering economic indicator system [Figure made by the authors].

According to Fig. 1, the structure of engineering economic indicator system as a solution is used for the quantitative and qualitative data analysis of each system element, as well as for the identification of universally applicable and comparable characteristics in order to establish more favourable conditions for the development of nano-field and mitigate the risks of industry problem causes.

Novelty of the study is related to the authors' comprehensive and integrated assessment approach, including economic environment development levels and identifying indicators by their belonging to the defined indicator groups for the effective determination, study, comparison and management of nano-field development to promote and develop the interaction of science and business in Latvia.

\section{ASSESSMENT OF THE ECONOMIC INDICATORS}

In Latvia, the nano-field develops in different industries, which have different investment parameters and quality of the labour force; therefore, the manufacture and use of innovative materials are interdisciplinary, as well as high-tech industry 
volume is difficult to be identified. However, based on previous theoretical reasoning and assessment that allow identifying the most important economic, social and technical indicators of nano-field development and use, the authors have performed an in-depth analysis of these indicators at the macro, meso and micro levels and developed economic, social and technical indicator groups (see Fig. 2).

\section{Economic Indicators}

At the macro or global level, the economic indicator group includes economic development indicators that were elaborated by analysing large data arrays due to the need to universally compare the countries of the world and cover as more development areas as possible. Thus, the authors use the global innovation index (GII) and global competitiveness index (GCI) (see Fig. 2), where GII is characterised by the multi-dimensional facets of innovation, capabilities and measurable results, and this means competitiveness of a particular economy, taking into account national productivity and prosperity.

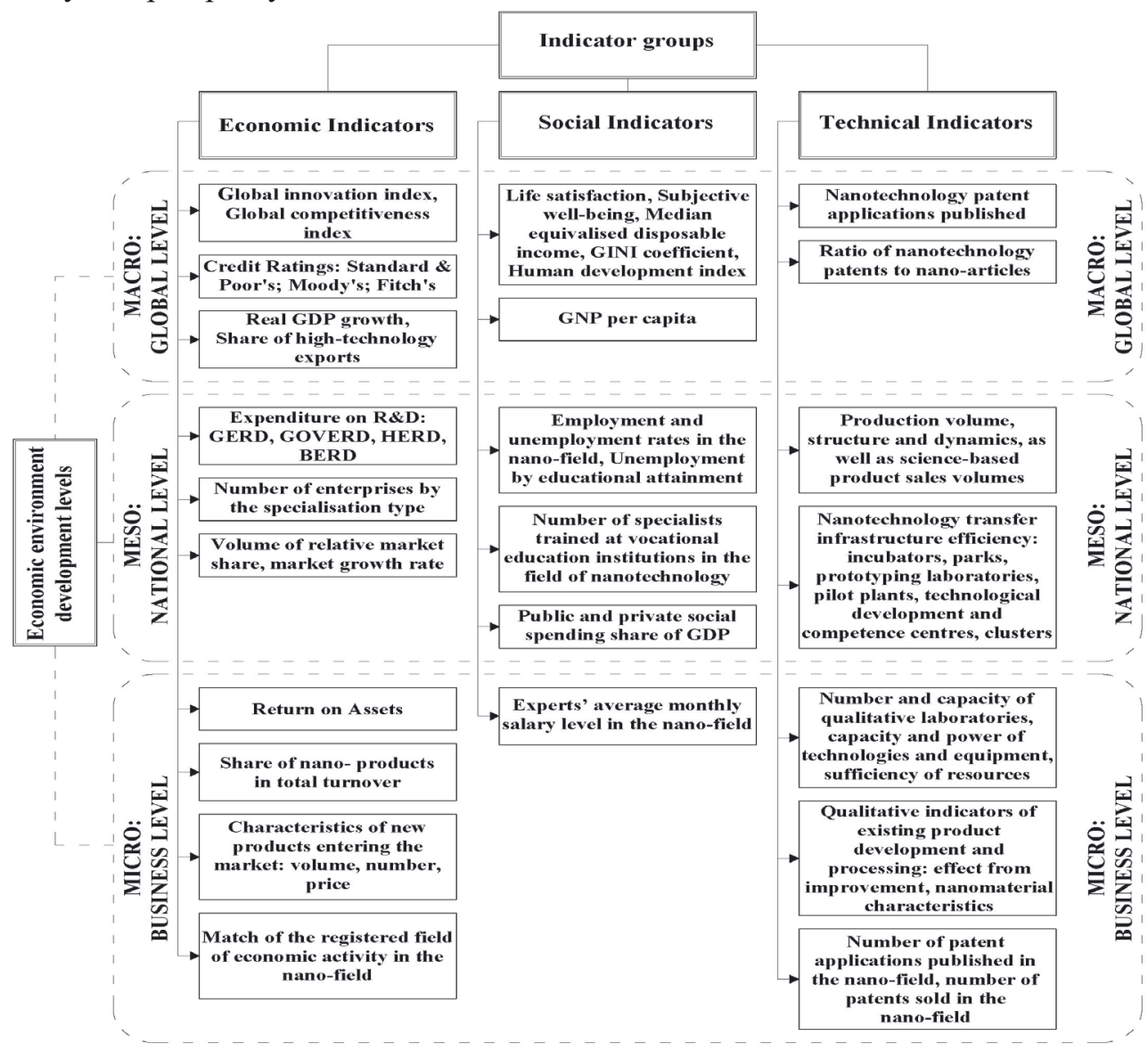

Fig. 2. Economic, social and technical indicator groups for assessment of the development of nanotechnologies and advanced materials industry [Figure made by the authors].

Out of 141 countries, Latvia took the 33rd position in the GII ranking as of 6 October 2015 with 0.77 percentage rank. In contrast, neighbouring Estonia was placed $23 \mathrm{rd}$ with 0.84 percentage rank, while a situation experienced by Latvia was 
also characteristic of Malaysia (32nd position with 0.78 percentage rank), Cyprus and Hungary (34th position with 0.76 percentage rank and 35 th position with 0.76 percentage rank, respectively). A substantial difference among the above-mentioned countries compared to Latvia is related to research and development financing from foreign funds: the highest rate is observed in Latvia (52\%), the lowest - in Malaysia (5\%); and business investment: the lowest proportion of GDP is characteristic of Latvia (22\%), the highest - of Malaysia (60\%) [12]. In relation to the GCI, out of 144 countries Latvia was ranked 42nd in the reporting period of 2014-2015, where the same value of 4.5 was reached by the Czech Republic, Azerbaijan, Mauritius, Kuwait, Lithuania, Poland, Bahrain. By contrast, neighbouring Estonia was ranked 29th in the GCI report [13]. Latvia's 42nd position is evaluated positively since in the previous report of GCI Latvia was ranked 52nd, i.e., within a year, it jumped by 10 positions. It is also important to note that this indicator can be characterised as innovation (availability of scientists and engineers; government procurement of advanced technology products; capacity of innovation), public institutions and infrastructure [14], where the evaluation of Latvia's performance is very low.

According to Fig. 2, at the macro level in the economic indicator group a significant role is played by credit rating, which is taken into account to evaluate the financial credibility of country and enterprises, which is also an important indicator to promote the development of nano-field in science and entrepreneurship in Latvia. As of 7 October 2015, Latvia's credit rating was defined as "stable outlook and upper medium grade" [15].

Compared with other European Union (EU) countries, Latvia was ranked among Slovakia (2.5\%) and Sweden (2.3\%) [16]. This demonstrates that the private consumption of households, the amount of investment provided by businesses and lending policy in Latvia do not achieve sufficient growth.

To determine the Latvian economic development trends and global challenges, the authors characterise the Latvian export structure and largest export industries in 2014, distinguishing the following product groups. The largest group is wood and wood products; charcoal (16.9\% in 2014), electrical appliances and electrical equipment $(11.3 \%)$, machinery and mechanical appliances $(5.1 \%)$, vehicles, excluding railway or tramway rolling stock, and their parts $(4.1 \%)$, iron and steel $(3.6 \%)$, iron or steel products (3.4\%) and pharmaceuticals (3.0\%) [17]. The report on the National Development Plan of Latvia until 2020 states that "in Latvia, there is a numerically small proportion of high-tech industries, which is also demonstrated by the share of high-tech products in the total exports that was $8 \%$ in 2013", which is almost two times lower than the EU average (in 28 countries) [18]. By contrast, the share of high-tech export final value (i.e., high-tech export is less than re-export) in the foreign trade in Latvia (5.8 \%) and in neighbouring Lithuania (4.8\%) is among the lowest in the world. By the highest intensity industries, the lowest profitability is demonstrated by Latvia - only $14 \%$, in Lithuania this indicator is $21 \%$. In turn, Malaysia that is compared to Latvia based on the GII ranking has reached quite a high level of $42 \%$, Estonia's achievement is somewhat lower - $38 \%$, while in Hungary - almost $50 \%$ [12]. This analysis of export structure shows that the production of low or medium-low technology sectors dominates, and export profitability is low. Share of manufacturing industry is small in the Latvian economy, although exactly 
the manufacturing industry and related service sectors play an important role in the creation of innovations and technologies. It should also be noted that not in all these sectors there is a demand for research and knowledge.

At the meso or national level, in the economic indicator group an important role is played by expenditure on R\&D by sector and its financing: GERD GOVERD, HERD, BERD. In Latvia, expenditure on research activities by sector (business sector, public sector and higher education sector) and their financing accounted for only $0.68 \%$ of GDP in 2014 [19]. For comparison purposes, in 2013 the total funding for scientific research in Latvia amounted to $0.6 \%$ of GDP, holding approximately similar positions with Bulgaria, Cyprus and Romania. In comparison with neighbouring countries, in 2013 Lithuania's expenditure on research activities accounted for $0.95 \%$ of GDP, but in Estonia it was $1.74 \%$ [20]. According to the analysed data, Latvia has one of the lowest business R\&D intensities in the EU as well as one of the worst criteria in Europe, i.e., expenditures on R\&D. The same low evaluation of Latvia has been demonstrated by the previously analysed GCI innovation index. However, according to the data of survey carried out by the authors, only using the existing capacities, intensive growth is expected in manufacture of machinery and equipment, aviation and space industry, as well as in production of health industry, biomedicine, and biotechnology - a total of more than $7 \%$ of the potential competence growth [1]. R\&D potential, as evidenced by the willingness of local highly qualified specialists to participate in interdisciplinary and international projects, in Latvia after regaining its independence still emphasises the critical need for research development in order to promote the future growth of Latvia. GERD indicator in relation to Latvia and the comparison with other countries will be analysed under the technical indicator group at the business level, which is an important tool for the development of innovative products. Taking into account a low level of R\&D growth in Latvia, the Latvian government should consider R\&D potential threats as these negative R\&D indicators prevent the purposeful introduction and use of modern materials in the Latvian economy. According to the report as of 8 September 2015 on achieving national development goals within the Latvian Sustainable Development Strategy until 2030 and the implementation of the Latvian National Development Plan from 2014 to 2020 [18], already in 2017 the GERD level is expected to grow at a moderate pace, reaching $1.2 \%$ of GDP in 2017 and $1.5 \%$ of GDP in 2020 . But it is quite ambitious to plan to increase the GOVERD and HERD from the level of $0.17 \%$ in 2012 to $0.65 \%$ (almost four-fold increase) by 2017, and BERD - from $0.16 \%$ in 2012 to $0.55 \%$ of GDP in 2017 . The government envisages an increase in investment activities by the private sector with the introduction of the corporate income tax relief for R\&D expenses (6. ${ }^{6}$ Article. Expenses on Research and Development. Law “On Corporate Income Tax") [21], as well as plans the transformation of national economy in favour of production of goods and services with higher added value and will continue to attract financial instrument assets.

As the next indicator in the economic indicator group at the meso level, the authors distinguish companies by the specialisation type: the material extraction process; the type of created materials; and the used technology. The authors have studied the operation profile of innovative multifunctional material manufacturers, and according to the survey results the innovative multifunctional material manufac- 
turers in Latvia mostly produce non-metal and composite products. Most respondent companies are involved in physical and chemical manufacturing. Many of them have production in both profiles. Abrasion resistance is the main type of the produced multifunctional material characteristics in Latvia. The most popular multifunctional coatings are obtained from powder - $29 \%$ of all the respondents' answers; vacuum and deposited coatings are the second most popular type of technology used [1]. The Central Statistical Bureau of Latvia conducted its own survey of the period between 2010 and 2012, according to which the number of enterprises active in innovation accounted for $30.4 \%$ of the total number of enterprises and the majority of them or about $65 \%$ were large companies (more than 250 employees) [22]. More accurate data on the number of Latvian companies by various types of specialisation in the nano-field, as already mentioned in the theoretical part, are not available to the authors. The authors believe that it would be advisable to examine companies by the specialisation type in the nano-field as a study object in order to be able to identify market potential of nano-field, improve existing products and materials, as well as to prevent potential obstacles and risks in the entrepreneurship.

The same problem is attributed to the competitiveness indicators at the meso level; it is still early to forecast and determine the Latvian relative market share and market growth rate in the nano-field. As analysed above, the GCI is of major importance in determining national economic competitiveness, which is affected by many factors: institutions, infrastructure, macroeconomic environment, health and primary education, higher education and training, goods market efficiency, labour market efficiency, financial market development, technological readiness, market size, business sophistication and innovation.

At the micro or business level, the economic indicator group comprises return on assets (ROA); share of nano-products in total turnover; characteristics of new products entering the market: the volume, number, price; match of the registered field of economic activity in the nano-field. Thus, according to results of the survey performed by the authors, "only $24 \%$ of the manufacturing companies producing innovative multifunctional materials in Latvia have specialisation in the high technology. Particular business units have reported very strong capabilities and high ROA ratio - over $25 \%$ and around $8 \%$. To be successful in promotion of the manufactured nano-products, most respondents pointed to the importance of the internal factors. Most of those companies have recently had a significant increase in a market share." [1].

The remaining economic indicators at the micro level are subjectively determined characteristics, which should be assessed through targeted research, because they require the involvement of corporate competencies and commercial data analysis. The type of nano-industry production and technology use is broad, which is not distinguished and reflected by the official statistics at present. For example, according to the mentioned survey results, the analysed businesses matched the registered activity very differently. Thus, data on the field, where respondent companies operated during the survey period, showed a $33 \%$ difference from the official register for the high technology intensity industry, i.e., the number of companies was 1.6 times higher for the production of computers, electronics and optical products [1].

Similarly, the share of nano-products in total turnover and the characteristics 
of new products entering the market are usually confidential, but informative and very valuable data that would be provided by companies only for targeted research or in case of audit. By contrast, evaluating the operation of enterprises when introducing new products, the survey data demonstrated that "the highest rivalry share and more intensive growth" in Latvia could be "in manufacture of machinery and equipment, aviation and space industry, production of health industry, biomedicine, biotechnology" [1].

Taking into account the analysis of economic indicators performed at all levels, the authors conclude that the most significant impact on the company or industry's external environment is exerted by a national policy. Sustainable public administration ensures predictable manifestations in the following areas - tax and innovation policy, investment environment, and lending policy. Therefore, in these areas Latvia should adopt not only conceptual, but also action-enhancing and supporting solutions in order to promote scientific research development.

\section{CONCLUSION}

1. Application of nanotechnologies in various sectors with different investment parameters and quality of labour force creates a need to identify the factors that influence the development of this field, the extent of effect and the indicators that can be used to assess this impact.

2. Developing the engineering economic indicator system, the authors have supplemented and adjusted the set of indicators that reflect the development of nanofield in the context of economic, social and technical indicators. The authors have systematised indicators by economic environment development levels and compared the available analytical data in Latvia with that in other countries.

3. The authors emphasise that there is a lack of availability of data in certain economic value positions, for example: the actual enterprise specialisation and activity types for identification of nano-field relative market share, qualitative indicators of product improvement and processing or nanoproduct and technology commercialisation indicators. The authors consider that such information can be obtained from organised surveys, which can be ensured within the target projects or through involvement of the competent institutions concerned, for example, the EuroNanoForum delegates - universities, ministries of economics, European Technology Platform of Nanotechnology.

4. The use of a uniform methodology for the analysis of nano-field performance and development trends of Latvian and foreign companies on the global scale and for transnational evaluation would provide the opportunity to define more precisely the development prospects and capacities of domestic market.

5. In Latvia, the major impact on the company or industry external environment is exerted by the public policy. Sustainable public administration provides predictable manifestations in the following areas - tax and innovation policy, investment environment, and lending policy. Therefore, in these areas Latvia should adopt not only conceptual, but also action-enhancing and supporting solutions in order to promote scientific research development. 


\section{REFERENCES}

1. Geipele, I., Staube, T., Ciemleja, G., Zeltins, N., \& Ekmanis, J. (2015). Identity of innovative multifunctional material manufacturing business in Latvia. Latvian Journal of Physics and Technical Sciences, 52 (4), 3-18. doi: 10.1515/lpts-2015-0019

2. Gholizadeh, H., Naeini, A. B., \& Moini, A. (2015). A quantitative model of technological catch-up. International Journal of Engineering \& Technology, 4 (1), 233-243. doi: 10.14419/ijet.v4i1.4203

3. Dessi, C., \& Floris, M. (2010). When management and customers see eye-to-eye: the agreement factor and performance. Journal of Small Business and Enterprise Development, 17 (1), 102-122. doi: 10.1108/14626001011019152

4. Niessen, S., \& Friedrich, R. (2009). Das Meistern der Krise für kleine und mittlere Unternehmen (KMUs): Erfolgsfaktoren und ihre Wirkung. OnlineBlatt 01/2009. Retrieved from http://www.malik-management.com/de/pdf/publikationen/online-letter/malik-online-letter-das-meistern-der-krise-fuer-kmus.pdf

5. Becerra, M. (2009). Theory of the firm for strategic management economic value analysis, Cambridge: Cambridge University Press. doi: 10.1017/CBO9780511626524

6. Parmenter, D. (2007). Key performance indicators: Developing, implementing, and using winning KPIs. 3rd ed. Hoboken: John Wiley \& Sons.

7. Cokins, G. (2004). Performance management: Finding the missing pieces (to close the intelligence gap). Chichester: John Wiley \& Sons.

8. Neely, A. (Ed.). (2002). Business performance measurement: Theory and practice. Cambridge: Cambridge University Press.

9. Epstein, M., \& Manzoni, J. (Eds.). (2006). Performance measurement and management control improving organizations and society. Bingley: Elsevier JAI.

10. Franceschini, F., Galetto, M., \& Maisano, D. (2007). Management by measurement: Designing key indicators and performance measurement systems. Torino: Springer Berlin Heidelberg. doi: 10.1007/978-3-540-73212-9

11. Geipele, I., Staube, T., Ciemleja, G., Geipele, S., Zeltins, N., \& Ekmanis, J. (2015). The development and design of engineering economic indicator system for nanotechnology industry product manufacturing: A case study of Latvia. Latvian Journal of Physics and Technical Sciences, 52 (5), 3-19. doi: 10.1515/lpts-2015-0024.

12. The Global Innovation Index. (2015). 2015 country ranking. Retrieved 19 October 2015, from https://www.globalinnovationindex.org/content/page/data-analysis.

13. World Economic Forum. (2014). Competitiveness rankings. . Retrieved 19 October 2015, from http://reports.weforum.org/global-competitiveness-report-2014-2015/rankings/

14. World Economic Forum. (2014). Latvia in the global competitiveness report, 2014 2015. Retrieved 19 October 2015, from http://www.nccl.lv/data/Logos/FDI\%20and\%20 investment\%20outlook_World\%20Econonomic\%20Forum.pdf

15. Trading economics. (n.d.).Latvia Credit Rating. . Retrieved 11 October, 2015, from http://www.tradingeconomics.com/latvia/rating

16. Eurostat. (n.d.). Real GDP growth rate - Volume. Retrieved 8 October 2015, from $\mathrm{http}: / /$ ec.europa.eu/eurostat/tgm/table.do?tab=table\&init=1\&language=en \&pcode=tec00115\&plugin $=1$.

17. Central Statistical Bureau of Latvia. (n.d.). Latvia's foreign trade. Main commodities and partners in 2014. Retrieved 8 January 2016, from http://www.csb.gov.lv/sites/default/ files/nr_28_areja_tirdznieciba_preces-partneri_14_04_lv.pdf (in Latvian). 
18. National Development Plan of Latvia's Portal (2015). The prime minister will report on achieving the national development objectives and implementation of the NAP2020. Retrieved 5 January 2016, from: http://www.pkc.gov.lv/443-inistru-prezidente-zi\%C5\%86os-par-valsts-att\%C4\%ABst $\% \mathrm{C} 4 \%$ ABbas-m\%C4\%93r\%C4\%B7u-sasnieg\%C5\%A1 anu-un-nap2020-\%C4\%ABsteno\%C5\%A1 anu (in Latvian).

19. Central Statistical Bureau of Latvia. (n.d.). Expenditure on research activities by sector and their financing (mln. EUR) Retrieved 5 January 2016, from http://data.csb. gov.lv/pxweb/lv/zin/zin_zin/ZI0030_euro.px/table/tableViewLayout1/?rxid=ce8aac91-f2b0-4f13-a25d-29f57b1468fb (in Latvian).

20. Eurostat statistics explained. (n.d.). Europe 2020 indicators - Research and development. Retrieved 15 November 2015, from http://ec.europa.eu/eurostat/statistics-explained/index.php/Europe_2020_indicators___research_and_development.

21. LR Legislation. (2015). Law on Corporate Income Tax. Retrieved 9 January 2016, from http://likumi.lv/doc.php?id=34094 (in Latvian).

22. Central Statistical Bureau of Latvia. (n.d.). Informative survey "Innovation in Latvia for 2010-2012”.. Retrieved 15 November 2015, from http://www.csb.gov.lv/sites/default/ files/nr_37_inovacijas_latvija_14_00_lv.pdf (in Latvian).

\title{
NANOTEHNOLOGIJUUNVIEDOMATERIĀLUINDUSTRIJASATTĪSTĪBA ZINĀTNESUNUZN̄ĒMĒJDARBĪBAS JOMĀS: SOCIĀLEKONOMISKIEUN TEHNISKIE RĀDİTĀJI. LATVIJAS PIEREDZE (PIRMĀ DAḶA)
}

\author{
I. Geipele, S. Geipele, T. Štaube, G. Ciemleja, N. Zeltiņš,
}

Kopsavilkums

Dotais zinātniskais raksts ir viens no divām ieplānotajām publikācijām, kurās autori apkopo zinātniskā pētījuma gaitā iegūtos rezultātus. Šis darbs ir zinātnisko rakstu sērijas turpinājums, veltīts nanotehnologiju un viedo materiālu industrijas attīstības līmeņa noteikšanai un paaugstināšanai zinātnē un uzṇēmējdarbības jomā Latvijā. Pētījumam autori ir uzstādījuši mērķi noskaidrot īpaši nozīmīgos sociālekonomiskos un tehniskos rādītājus. Šādi, šis raksts sniedz apkopojumu par pētījuma diapazonu, kā arī ietver sevī izstrādāto inženierekonomisko rādītāju sistēmas struktūru, rādītāju grupas nanotehnolog̣iju un viedo materiālu industrijas attīstības noteikšanai Latvijā un statistisko datu izvērtējuma rezultātus par ekonomiskajiem rādītājiem.

07.03.2016. 